\title{
Cytological Effects of Water Extracts of Medicinal Plants \\ I. Influence of Ammi majus extract on root tip of Vicia faba
}

\author{
Z. M. Adam and Th. Rashad \\ University College for Girls, Ain Shams University, Cairo, U.A.R.
}

Received August, 21, 1981

The use of plant extract instead of synthetic drugs in the treatment of some diseases increased progressively. Many investigarors made trials to test the mode of action, toxicity, physiology and cytology of some plant extracts. Among them Marquardt (1950), Ohno (1960), Sarkar (1974), Abraham et al. (1976) and Shehab (1979 and 1980).

The water extract of Ammi majus (Khella) seeds is used in the treatment of leucodermia and skin diseases (El-Antaki 1923). This plant grows wild in U.A.R. and it belongs to family Umbelliferae, the inflorescence is a compound umbel and the fruit is a schizocarp that splits into two one-seeded mericarps. When boiled with water the seed extract is yellowish brown, possessing a specific odour and a pungent taste. The active component of the extract is xanthotoxin (Balbaa et al. 1976).

\section{Material and methods}

The test plant was Vicia faba (var. Rebaya 40). The plant extract was prepared by boiling a weighed quantity $(0.5,1$ and $10 \mathrm{gm})$ of the dry ripe fruits in $100 \mathrm{ml}$ distilled water for 10,20 and 30 minutes. The evaporated water was replaced to the original volume. The germinated seeds were treated by dipping the roots in the experimental extracts for three time durations (2, 4 and 6 hrs.) besides the control. In addition a group of seeds were taken off each treatment and placed in distilled water for $24 \mathrm{hrs}$. to study the effect of recovery.

\section{Results and discussion}

The induction of mitotic index decline in all treatments was not correlated with time in both direct and recovery experiments. Generally the 6 hour exposure of Vicia faba root tips showed toxicity in 10,20 and 30 minutes extracts, as can be seen from Table 1.

Mitotic disturbance leading whether to decrease or increase of mitotic index was reported by many authors, Amer and Ali (1969), Badr et al. (1972), Nancy and Sandra (1974), Jurgen (1975) and Francis and Macleod (1977).

Table 1 showed also prophase percentage rose over control in most treatments especially after recovery. Metaphase percentage was also higher, these increments in prophase and metaphase percentages were on the expence of ana-telophases. 
The results showed that the effect of Ammi majus extracts was inhibitory in short durations and lethal in long ones where toxicity occurred in most recovery experiments, this may be explained on the assumption of the high penetrability of the extract and the fast reaction inside the cell. Galal and Abd-Alla (1976) reported similar results in treating root tips with sodium fluoride and diethyl amine.

Table 1. Mitotic index and percentage of mitotic phases of Vicia faba as affected by the extract

\begin{tabular}{|c|c|c|c|c|c|c|c|c|c|}
\hline \multirow{3}{*}{\multicolumn{2}{|c|}{ Treatment }} & \multirow{2}{*}{\multicolumn{2}{|c|}{$\mathrm{MI} \%$}} & \multicolumn{6}{|c|}{ Mitotic phases } \\
\hline & & & & \multicolumn{2}{|c|}{ Prophase } & \multicolumn{2}{|c|}{ Metaphase } & \multicolumn{2}{|c|}{ Ana-telophase } \\
\hline & & D. & $\mathrm{R}$. & D. & $\mathbf{R}$. & D. & $\mathbf{R}$. & D. & $\mathrm{R}$ \\
\hline \multirow{2}{*}{\multicolumn{2}{|c|}{$\begin{array}{l}\text { Control } \\
10 \text { min. ext. }\end{array}$}} & 8.4 & 7.5 & 43.7 & 30.8 & 22.1 & 28 & 35.9 & 42.1 \\
\hline & & & & & & & & & \\
\hline \multirow[t]{3}{*}{$0.005 \%$} & $2 \mathrm{~h}$ & 5.2 & 5.7 & 46.5 & 39 & 30.8 & 23.7 & 22.7 & 22.2 \\
\hline & $4 h$ & 6.1 & 6.8 & 64 & 41.9 & 29.5 & 20.9 & 6.5 & 37.2 \\
\hline & $6 \mathrm{~h}$ & Toxic & Toxic & Toxic & Toxic & Toxic & Toxic & Toxic & Toxic \\
\hline \multirow[t]{3}{*}{$0.01 \%$} & $2 \mathrm{~h}$ & 4 & 4.6 & 54.4 & 43.1 & 23.5 & 34 & 22 & 23 \\
\hline & $4 h$ & 3.5 & 2.8 & 41.7 & 50 & 31.6 & 33 & 26.7 & 17 \\
\hline & $6 \mathrm{~h}$ & Toxic & Toxic & Toxic & Toxic & Toxic & Toxic & Toxic & Toxic \\
\hline \multirow[t]{3}{*}{$0.1 \%$} & $2 \mathrm{~h}$ & 4.4 & 4.8 & 52 & 56.4 & 26.8 & 22.8 & 20.9 & 20 \\
\hline & $4 \mathrm{~h}$ & 3.5 & 4.3 & 41 & 46.5 & 33.3 & 25.6 & 25.7 & 27.9 \\
\hline & $6 \mathrm{~h}$ & 3.2 & Toxic & 41.4 & Toxic & 35.8 & Toxic & 22.8 & Toxic \\
\hline \multicolumn{10}{|l|}{20 min. ext. } \\
\hline \multirow{3}{*}{$0.005 \%$} & $2 \mathrm{~h}$ & 5.3 & 5.3 & 48.4 & 58.1 & 30.5 & 14.6 & 20.6 & 22.3 \\
\hline & $4 h$ & 7 & 4.5 & 55.2 & 44.2 & 34.4 & 32.5 & 10.5 & 23.2 \\
\hline & $6 \mathrm{~h}$ & Toxic & Toxic & Toxic & Toxic & Toxic & Toxic & Toxic & Toxic \\
\hline \multirow[t]{3}{*}{$0.01 \%$} & $2 \mathrm{~h}$ & 4.9 & 5 & 71.4 & 63.2 & 20.4 & 23.7 & 8.2 & 20.9 \\
\hline & $4 h$ & 3.5 & 8 & 54.3 & 37.4 & 17.1 & 48.8 & 28.6 & 13.8 \\
\hline & $6 \mathrm{~h}$ & 2.8 & Toxic & 41.8 & Toxic & 45.5 & Toxic & 12.7 & Toxic \\
\hline \multirow[t]{3}{*}{$0.1 \%$} & $2 \mathrm{~h}$ & 4 & 5.2 & 50 & 54.3 & 22.2 & 26.7 & 27.8 & 19 \\
\hline & $4 h$ & 5 & 3.6 & 67.8 & 44.4 & 15.8 & 33.3 & 16.4 & 22.2 \\
\hline & $6 \mathrm{~h}$ & 3.1 & Toxic & 53.7 & Toxic & 27.2 & Toxic & 19.1 & Toxic \\
\hline \multicolumn{10}{|c|}{30 min. ext. } \\
\hline \multirow[t]{3}{*}{$0.005 \%$} & $2 \mathrm{~h}$ & 5.9 & 4 & 83.5 & 30 & 6.8 & 45 & 10.7 & 25 \\
\hline & $4 \mathrm{~h}$ & 5.4 & 3.2 & 67.3 & 43.8 & 23 & 34 & 8.3 & 21.9 \\
\hline & $6 \mathrm{~h}$ & 6.9 & Toxic & 51.3 & Toxic & 31.2 & Toxic & 17.5 & Toxic \\
\hline \multirow[t]{3}{*}{$0.01 \%$} & $2 \mathrm{~h}$ & 3.9 & 5 & 71.8 & 58.9 & 20.5 & 14.7 & 7.7 & 26.4 \\
\hline & $4 \mathrm{~h}$ & 3.2 & 7.1 & 40.6 & 49.7 & 43.1 & 20.2 & 16 & 30 \\
\hline & $6 \mathrm{~h}$ & 7.2 & Toxic & 47.8 & Toxic & 27 & Toxic & 25.1 & Toxic \\
\hline \multirow[t]{3}{*}{$0.1 \%$} & $2 \mathrm{~h}$ & 6.4 & 4.5 & 66.2 & 44.4 & 17.8 & 22.2 & 22 & 33.4 \\
\hline & $4 \mathrm{~h}$ & 4.9 & Toxic & 41.9 & Toxic & 25.8 & Toxic & 32.3 & Toxic \\
\hline & $6 \mathrm{~h}$ & 4.2 & Toxic & 53.1 & Toxic & 20.7 & Toxic & 26.2 & Toxic \\
\hline
\end{tabular}

D, direct. R, recovery.

The mitodepressive effect of the extract may be due to lengthening of mitotic cycle time and or delaying of spindle formation rather than affecting the cell in the $G_{1}, S$ or $G_{2}$ phases where DNA replication takes place. The extract may also affect nuclear membrane distintegration because of the high percentage of irregular prophases and prophase accumulation. This type of prophase abnormality was 


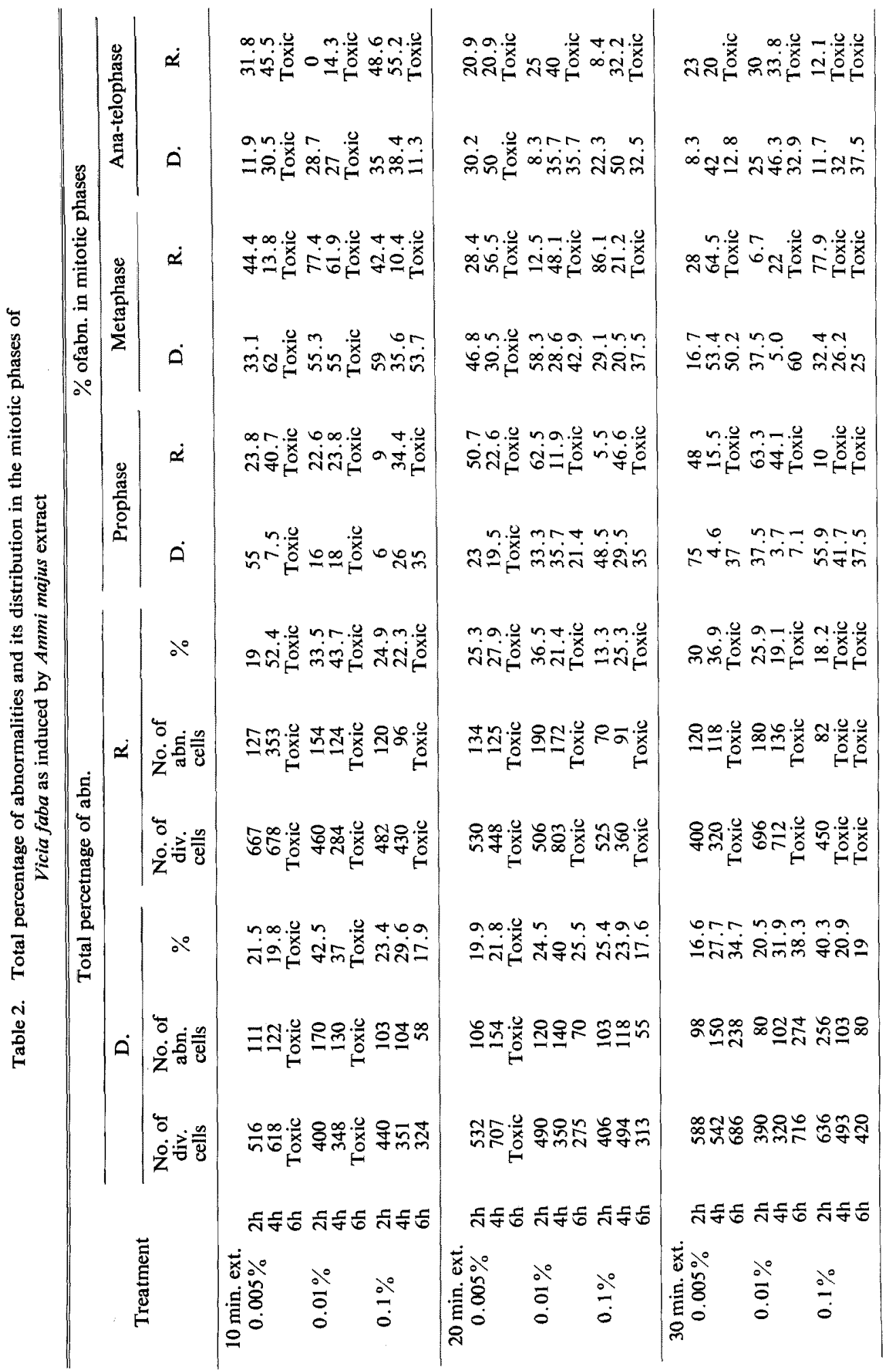




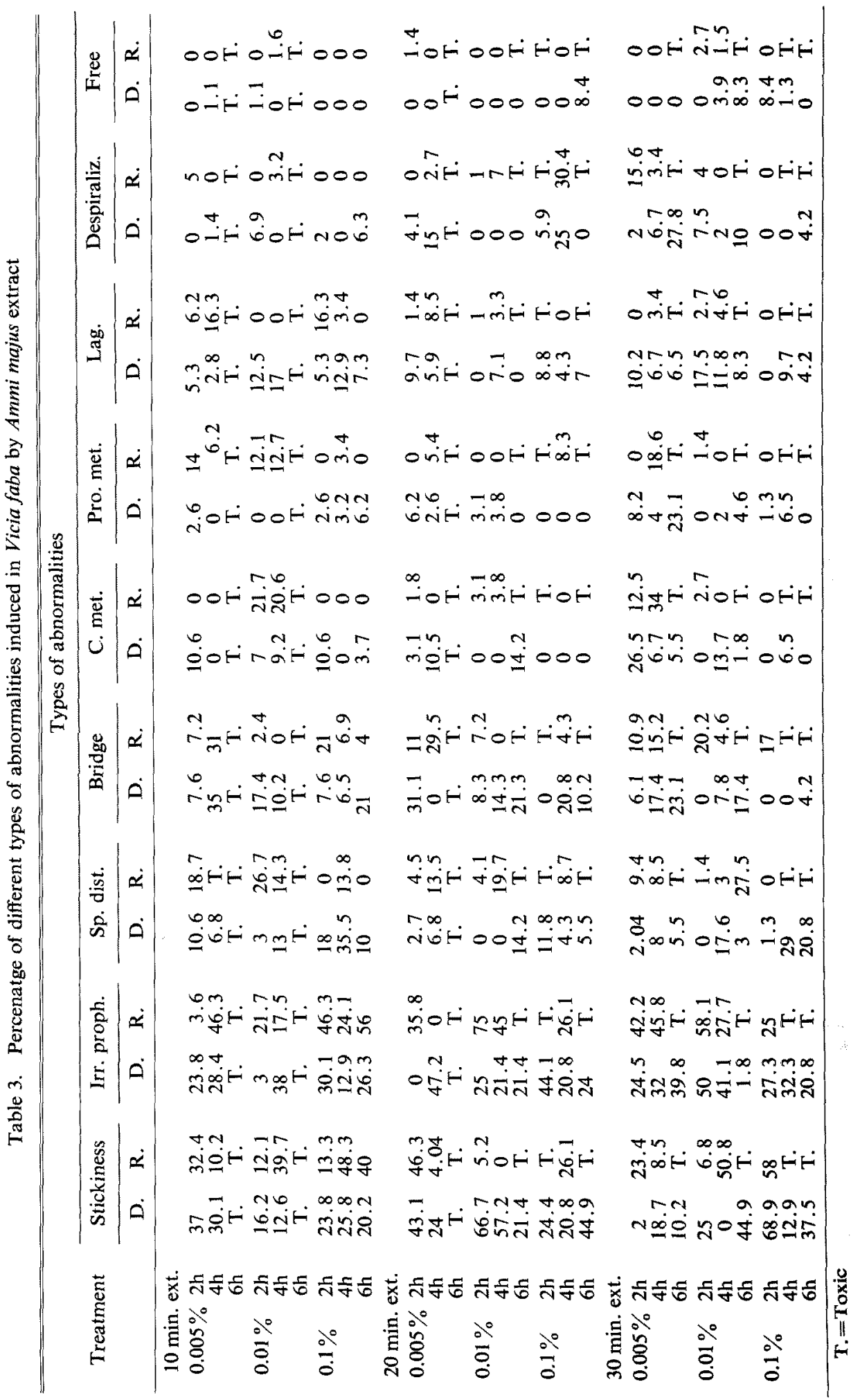


reported by Kabarity (1966) who opined that the agents used hindered the individualization of chromatic material.

Concerning the three extracts 10,20 and 30 minutes boiling, it is clear that

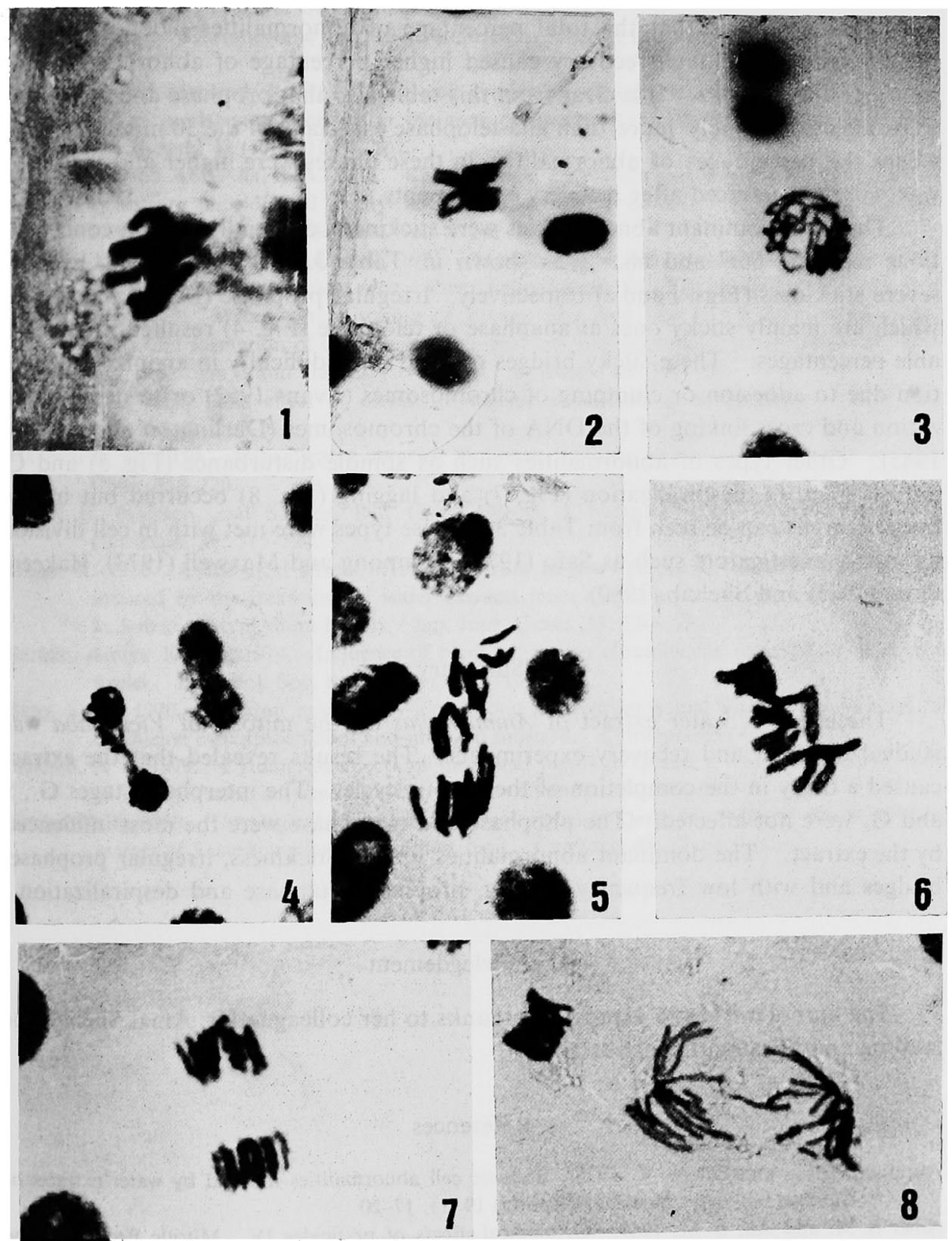

Figs. $1-8$. 1, light stickiness in metaphase $(2 \mathrm{hr}, 0.005 \%, 10 \mathrm{~min}) .2$, severe sticky metaphase $6 \mathrm{hr}, 0.1 \%, 20 \mathrm{~min})$. 3, irregular prophase $(4 \mathrm{hr}, 0.005 \%, 10 \mathrm{~min}) .4$, sticky bridges in telophase $(6 \mathrm{hr}, 0.1 \%, 10 \mathrm{~min}) .5$, disturbed anaphase $(2 \mathrm{hr}, 0.01 \%, 30 \mathrm{~min}) .6$, C-mitosis $(4 \mathrm{hr}, 0.005 \%$, $30 \mathrm{~min}) .7$, despiralization in anaphase $(6 \mathrm{hr}, 0.005 \%, 30 \mathrm{~min}) .8$, lagging chromosomes $(2 \mathrm{hr}$, $0.01 \%, 30 \mathrm{~min})$. 
the 30 minutes extract was the least in induction of mitotic injury especially in direct treatments as compared to the control $(8.4 \%)$. This may be ascribed either to degradation of some of the active components affecting cell division by boliing or because of other constituents goes into solution having a neutralizing effect.

Table 2 showed that the total percentage of abnormalities did not follow a regular pattern although recovery caused higher percentage of abnormalities in a number of treatments. It is clear from this table also that prophase and metaphase were affected severely more than ana-telophase especially in the 30 minutes extract where the percentages of abnormalities in these phases were higher and that effect was more pronounced after recovery experiments.

The most dominant abnormalities were stickiness, expecially at high concentrations reaching 66.7 and $68.9 \%$ as shown in Table 3. It varies from light to severe stickiness (Figs. 1 and 2) respectively. Irregular prophase (Fig. 3) and bridges which are mainly sticky ones at anaphase or telophase (Fig. 4) resulted in appreciable percentages. These sticky bridges resulted from difficulty in anaphase separation due to adhesion or clumping of chromosomes (Evans 1962) or to depolymerization and cross linking of the DNA of the chromosomes (Darlington and LaCour 1945). Other types of abnormalities such as spindle disturbance (Fig. 5) and Cmitosis (Fig. 6), despiralization (Fig. 7) and lagging (Fig. 8) occurred but in low frequencies as can be seen from Table 3. These types were met with in cell division by many investigators such as Sato (1970), Bempong and Maxwell (1973), Hakeem et al. (1975) and Shehab (1980).

\section{Summary}

The effect of water extract of Ammi majus on the mitosis of Vicia faba was studied in direct and recovery experiments. The results revealed that the extract caused a delay in the completion of the mitotic cycle. The interphase stages $G_{1}, S$ and $\mathrm{G}_{2}$ were not affected. The phophase and metaphase were the most influenced by the extract. The dominant abnormalities were: Stickiness, irregular prophase, bridges and with low frequency lagging, prophasemetaphase and despiralization.

\section{Acknowlegdement}

The author wishes to express her thanks to her colleague Dr. Amal Shehab for reading and revising the manuscripts.

\section{References}

Abraham, Susan and Dileep, V. 1976. Somatic cell abnormalities induced by water extracts of Gloriosa superba. Nucleus (Calcutta) 19 (1): 17-20.

Amer S. M. and Ali, E. M. 1969. Cytological effects of pesticides IV. Mitotic ffects of some phenols. Cytologia 34 (4): 533-540.

Badr, E. A., Mourad, A. H. and Naguib, F. A. 1972. Effect of nitrous acid on the cell cycle and the mitotic apparatus in Vicia faba. Egypt. J. Genet, Cytol. 1 (2): 231-246.

Balbaa, S. I., Hilal, S. H. and Zaki, A. Y. 1976. Medical Plant Constituent. Second Edition: 543-538. 
Bempong, Maxwell A. 1973. Interaction of daunomycin with meiotic chromasomes in Vicici faba. Can. J. Genet. Cytol. 15 (3): 587-595.

Darlington, C. D. and La Cour, L. F. 1945. Chromosome breakage and the nucleic acid cycle. Jour. Genet. 64: 267.

El-Antaki, D. 1923. Tazkaret Oli El-Albab 3: 1-32.

Evans, H.J. 1962. Chromosome aberrations induced by ionizing radiations. Int. Rev. Cytol. 13: 221-331.

Francis, D. and Macleod, R. D. 1977. Some cytological changes accompanying the regeneration of meristematic activity at the apex of decapitated roots of Vicia faba. L. Ann. Bot. (Lond.) 41 (176) : 1149-1162.

Galal, M. E. and Abd-Alla, S. A. 1976. Chromosomal aberration and miotic inhibition induced by sodium fluoride and diethyl amine in toor-tips of Allium cepa, Allium sativum and Vicia faba. Egypt. J. Genet. Cytol. 5: 262-280.

Hakeem, H., Shehab, A. and Adam, Z. 1975. Morphological and cytological effects of nemagon and nemacur on Vicia faba. Proc. Egypt. Acad. Sci. 28: 153-160.

Jurgen, Reib 1975. Mycotoxin poisoning of Allium cepa root tips II. Reduction of mitotic index and formation of chromosomal aberrations and cytological abnormalities by patulin, rubratoxin B and diacetoxyscrirpenol. Cytologia 40: 703-708.

Kabarity, A. 1966. The effect of certain mutagenic substances upon prophases. Beitr-Biol. Pflanzen 42: 317-326.

Marquardt, H. 1950. Abban karpenreigener stobbeals mutagen. Agentein. Proc. 7th. Int. Bot. Cong. 218-220.

Nancy E. Peterson, and Sandra, Bell 1974. Effects of hycanthone on root of Vicia faba. Cytologia 39: 515-524.

Ohno, R. 1960. Cytological effects of extracts from noxious plants. I. Meiotic abnormalities induced by the treatment of water extracts from Cicuta virosa L. in Allium victoriales L. Subsp. platyphyllum hulten. Jap. Jour. Genet. 35: 120-124.

Sarkar, Amiya Kumar 1974. Influence of plant extrats on chromosome metabolism of mature nuclei. Bull. Bot. Soc. Bengal. 28 (1/2): 113-115.

Sato, Syoiti 1970. Electron microscopy on mitotic and chromosomal aberrations induced by colchicine mercaptoethanol and nitrogen mustard. Cytologia $35(3): 415-422$.

Shehab, A. S. 1979. Cytological effects of medicinal plants in Quatar I. Mitotic effect of water extract of Pulicaria crispa on Allium cepa. Cytologia 44: 607-613.

Shehab A. S. 1980. Cytological effects of medicinal plants in Qatar II. Mitotic effects of water extract of Teucrium pilosum on Allium cepa. Cytologia 45: 57-64. 